\title{
On the Future of Maritime Transport - Discussing Terminology and Timeframes
}

\author{
C. Hult, G. Praetorius \& C. Sandberg \\ Kalmar Maritime Academy, Linnaeus University, Sweden
}

\begin{abstract}
This paper offers an analytical discussion on the terminology and timeframes related to the future of shipping. The discussion is based on issues that have surfaced within the Swedish research project Autonomy and responsibility. The paper argues that the concept 'autonomous ships' has become an indicator of that seafarers soon will become obsolete - which may have negative consequences for the supply of maritime competence in coming years - and that the proper definition of the term 'autonomous' describes something that will never apply to a ship. Ships can be given the possibility, but hardly the full right or condition of selfgovernment. It is argued that 'smart ships', or perhaps 'intelligent ships', are more appropriate, since these terms describe the current and future state of technology without predicting how humans will prefer to use it. The estimated timeframes for implementation of unmanned ships suggest no threat to the seafaring occupation for coming generation. The content of the occupation will of course change due to the phase of implementation of degree of digitalization, but there will always be a need for maritime knowledge and understanding.
\end{abstract}

\section{INTRODUCTION}

This discussion paper takes its departure in the current development towards the future of shipping. It is believed that terminology and timeframes need to be analyzed in the light of possibilities and obstacles for the transformation into the next generation of maritime transport. The steppingstone is the belief that technical developments and its terminology need to be kept in-tuned with changing educational demands and organizational changes.

The main arguments in the paper stem from discussions in seminars, conferences, and several interviews with industry-related respondents. These activities have all taken place within the research project Autonomy and responsibility - The human role in the future of shipping, financed by the Swedish Transport Administration.

\subsection{The background}

In recent years, there has been an intense focus on transforming maritime transport based on increased automation and digitalization. The initiatives focus primarily on the development of technical systems that aim to support safety and efficiency in maritime transport where the ultimate outcome is often described as autonomous and unmanned vessels (e.g. MUNIN project, 2016; Rylander \& Man, 2016; WMU, 2019). Related projects have also addressed the interaction between operators and advanced technologies on board and ashore (e.g. Porathe, 2015; Porathe \& Billesø, 2015). What has been missing up to recently are analytical attempts to forecast the organizational development and the role of human operator in the future of maritime transport (c.f. Relling et al., 2018). 
From a historical point of view, the technical development in shipping has resulted in some major changes in organization, competence requirements, and in the preconditions for professional motivation and identification. One example is the transition from sails to steam-driven shipping. This transition brought about a shift in competence demands and over time - a change from hard physical work and exposure, into the environment that nowadays is often associated with physical inactivity, paperwork and fatigue (Allen et al., 2007; Lützhöft et al. 2010).

Changes are often for the better, but they also have a tendency to bring about unforeseen side effects. One source of such side effects is that technology changes on board with the aim to increase safety in operations, in reality foremost will be used to increase productivity and efficiency. One example of this is the introduction of radar technology that not only led to better navigation guidance but also to the increase of possible speed of the vessels, which in turn led to the presence of so-called "radar-assisted collisions" (Perrow, 1999). With this in mind, it has been argued that the analysis of changes within a system should be based on a holistic approach (Perrow, 1999). This means that we should not only consider how organization, technology and operator roles change but also how their interactions are affected by these changes. In this paper, the attempt is to take one careful step towards such a holistic approach considering the pre-transition terminology in relation to obstacles and possibilities surrounding the transformation into the next generation of shipping.

One side effect from the present focus on technical development towards the shipping industry of the future is that the concept 'autonomous ships' has become a buzzword that easily can be perceived as indicating that society is on the brink of an era where seafarers are no longer needed (e.g. Sjöfartstidningen, 2016; Aftonbladet, 2017; MAREX, 2017; World Maritime News, 2018). As such, the terminology signals that it would be a mistake for young people to apply for maritime studies because there will soon be no jobs in the sector. In fact, with start in 2016 the applications for ship officer studies has dropped dramatically in Sweden (Sjöfartstidningen, 2016, 2017), which will have negative impact on the supply of competence in coming years (Lighthouse, 2018).

\subsection{The terminology}

As already mentioned, the term 'autonomy' has been frequently used when predicting the future of shipping. In an attempt to describe the transition into the future, different steps or levels of autonomy have been elaborated. Lloyds Register has suggested six levels above manual, where the sixth is full autonomy (DMA, 2016), while DNV GL has suggested five levels (including manual as level one) for navigation functions, where the fifth is autonomous (DNV GL, 2018). As the latest of those framework-like definitions, IMO has instead suggested four nonhierarchical degrees of autonomy (Table 1), indicating that one or more degrees can be used for the same journey although the ship technically may be prepared for full autonomy (IMO, 2018).
Table 1. Degrees of autonomy, IMO

- Ship with automated processes and decision support: Seafarers are on board to operate and control shipboard systems and functions. Some operations may be automated.

Remotely controlled ship with seafarers on board: The ship is controlled and operated from another location, but seafarers are on board.

- Remotely controlled ship without seafarers on board: The ship is controlled and operated from another location. There are no seafarers on board.

Fully autonomous ship: The operating system of the ship is able to make decisions and determine actions by itself.

The introduction of 'non-hierarchical degrees' helps to envision different possible scenarios in the transition to the maritime future. Indeed, continued adjustments of the terminology is important for achieving a common perspective of the process.

The existing terminology has already been challenged by Relling et al., (2018: 350-362) who stressed the lack of coherence in how the terms, 'autonomy', 'automation' and 'unmanned' are at times interchangeably used in the maritime industry. The authors further discussed that there are several standard definitions of 'autonomy' presented; for example: "The right or condition of self-government" and the "Freedom from external control or influence; independence" (Oxford Living Dictionaries, 2018). Relling et al. also make the interesting observation that the definitions are well suited for the "explorers who sailed into the unknown more than 700 years ago" (Relling et al., 2018: 352). However, the authors decide to stick to the term, arguing that it refers to a process that "implies a significant change to the system" (Relling et al., 2018: 352).

It seems agreeable that the definition of 'autonomy' applies to the explorers in the Middle Ages since they had virtually no possibilities for long distance communication. However, it does not apply at all to their ships. The ship's performance was at the time strictly dependent on the crew. To be precise, it was rather the long distance maritime transport, which was autonomous at the time. However, the level of autonomy in maritime transport has since then steadily decreased following the technological developments of communication. Today, and thanks to the technology, the autonomy of maritime transport is closing in to nil. Given this development, we should ask ourselves if we sincerely believe that we will see autonomous maritime transport again.

Does this mean that the proper definition of the term 'autonomous' describes something that may never apply to a maritime concept in the shape of a ship? Well, it can be argued that it does not matter to what degree the ship's technology is developed, its intelligence has anyway been programmed by humans, at one point. It can also be stressed that its activities will for the foreseeable future be overseen and controlled by humans. This is not to say that it would be technically impossible for vessels to navigate without human interference under the most complex circumstances. Instead, the argument rests on the assumption that ship owners and other stakeholders most likely will keep hold of the possibility to monitor and interact at any point of the journey. If that argument is correct, a ship will, as far 
as we can see from now, never become autonomous. It can be given the possibility, but hardly the full right or condition of self-government. If no one responsible is onboard, it is more likely that the degree of surveillance and monitoring from shore to ship will increase.

This is why we will argue that 'smart ships', or perhaps 'intelligent ships', would be more appropriate terminology than 'autonomous ships' since the former describe the current and future state of technological development without predicting how humans will prefer to use it in some future state of that development. Likewise, 'degrees of digitalization' would be more appropriate than 'degrees of autonomy'.

Let us briefly return to the concept 'maritime transport'. Given modern communication technology, it is difficult to find any good arguments for turning the clock back hundreds of years to the state of autonomous maritime transport. Therefore, this discussion could end here if it was not for the possibility of 'unmanned' maritime transport. A future of unmanned maritime transports on a global scale would indeed be the real significant change to the system. It brings to mind a future with huge cargo containers floating over our oceans like ghost-ships, constantly being possible targets of cyber-attacks and incapable to assist in any emergency on other vessels. On the positive note, these unmanned transports would most likely be monitored from distance with the option of human interference.

Given these arguments, we conclude that a proper understanding of the real conditions at sea should remain as a necessity for an employment as navigation officer, regardless if it is on ship or in a shore-based control center. Thus, the maritime academies should only sequentially adjust their curriculums for requirements that lies ahead. Therefore, we shall now look into the most likely timeframes of implementation given different concepts and combinations of type of ship and traffic area.

\subsection{The timeframes}

Unmanned and waterborne vehicles are already on the verge of becoming a reality for relatively short distance vessels in sheltered areas. The Finnish ferry Falco has successfully made its first voyage, monitored from a control center in Turku (Yle Uutiset, 2018). In Norway, the container vessel Yara Birkeland is waiting for its gradual transformation from manned- to unmanned operation to start (Yara Birkeland, 2019). In Sweden, the process is a bit slower. However, due to the Swedish climate goal of zero net emissions of greenhouse gases by 2045 (Government Offices of Sweden, 2017), a big portion of the country's archipelago ferries are now quickly modernized, which includes high levels of digitalization.

The timeframe for implementation will of course differ depending on the specific concept and segment that is considered to realize unmanned, or smart, maritime traffic. The concept suitable for the unmanned vessels in domestic traffic would be vessels remotely monitored from shore, equipped with artificial intelligence, learning from situations and being able to plan and implement the journey, which would correspond to degree three and four in Table 1. When it comes to unmanned ships in international water, things are getting more complicated. In Table 2, four combinations of ship type and traffic area are displayed (c.f. Praetorius et al., (2019). The categories are numbered 1-4, where 1 represents the combination where it seems likely that unmanned vessel traffic appear first and 4 where it is likely to appear last (or not at all).

Table 2. Timeframes and ship/area combination

\begin{tabular}{lcc}
\hline & Cargo Ships & Passenger Ships \\
\hline Domestic Traffic & 1 & 2 \\
International Traffic & 3 & $4-?$ \\
\hline
\end{tabular}

Thus, unmanned cargo vessels in domestic traffic are likely to be less challenging to implement (Table 2, cell 1.), followed by passenger vessels in the same traffic area (Table 2, cell 2.). Based on seminars and interviews, it is estimated that the timeframe for a significant level of implementation of these types of combinations is about 10-20 years from now, depending on traffic system complexity with recreational vessels and needs for adaptation of surrounding infrastructure.

The real difficulties for implementation will arise when it comes to longer distance transport of valuable gods. The general concerns in the development of unmanned international maritime traffic is that new, harmonized regulations have to be in place. Harbors have to be prepared or totally rebuilt and there is the need to provide sufficient IT-infrastructure to enable shore-based traffic monitoring as complement to current surveillance and monitoring services, such as VTS, coastguard or pilotage. Further, solutions for unanticipated and sometimes sudden maintenance and repairs must be in place. Sufficiently manned control centers and a secure defense against cyberpirates need to be defined and provided. An additional obstacle is the global political uncertainty, such as possible shifts towards protectionism and trade wars.

Given all the above-mentioned obstacles, a significant introduction of worldwide traffic for international unmanned cargo ships will probably take more than 40 years (Table 2, cell 3). The timeframe for international implementation of unmanned passenger ships remains a question mark (Table 2, cell 4).

Ships operated with help of artificial intelligence, learning from its operating context, would potentially also be suitable for international unmanned traffic. They may be remotely monitored from shore, but not necessarily. One alternative concept for long distance voyages may be the Convoy solution or Vessel Train, (NOVIMAR, 2017). Convoys have historically been used in wartimes and in recent years as protections against pirates. For the future, the convoy solution refers to one manned control vessel followed by several unmanned cargo vessels. Thus, although the transportation is manned the load capacity increases considerably in relation to the size of the crew. This concept may receive some scepticism, partly because 
the benefit of a stand-by crew would be dependent on the weather conditions, and partly because the initial costs may become too high.

For the transformation period, one possibly faster lane would be smart ships with lower manning, including partial monitoring from shore-based control centers. This could probably be implemented in domestic water rather swiftly. However, there may be a worry concerning this concept due to no backup crew and negative effects on the social work environment on board on longer voyages. The digitalization process has so far made it possible to decrease the crew to such a minimum that it could become socially harmful to decrease it further. Moreover, the question of how and if partial monitoring from distance could ever be sufficient to release the captain of the ship from responsibility must be solved.

Thus, the important question here is not when the level of technology is mature enough for unmanned maritime transport. The important question is instead when the ship owners will be prepared to invest in unmanned ships? The answer would be - not until all the above-mentioned obstacles are about to be solved. It also rather clear that for reasons of security and responsibility it is impossible to even discuss timeframes for oil tankers and passenger ships. Basically, the question of when, and even if, comes down to economy, security and responsibility.

To be more precise, the transit from manned- to unmanned maritime transport on a worldwide scale will not be a transition from contemporary smart ships to even smarter ones. It will rather require a total change of a worldwide system of transportation. Innovations are indeed a source for growth and productivity, but it would be "diffusion rather than invention or innovation that ultimately determines the pace of economic growth and the rate of change of productivity" (Rosenberg, 1972; Hall \& Khan, 2002: 2). For the case of maritime transport, diffusion means the rate to which ship owners, stakeholders and authorities in the whole system will adopt the technology outcome in the shape of unmanned transports. There are usually many barriers for such a rate to peek as it relies on individual decisions in complex systems. The barrier is not due to the option of adopting or not adopting to the new technology, but to the "choice between adopting now or deferring the decision until later" (Hall \& Khan, 2002: 3).

\section{CONCLUDING SUMMARY}

This article has aimed to contribute to the discussion on the terminology and timeframes in the current development towards the future of maritime transport. The focus has mainly been on predictions based on issues that have surfaced within the current research project Autonomy and responsibility.

Making predictions is indeed epistemologically difficult and very risky. It can, however be concluded that digitalization and automation will continue to increase intertwined with changes to how work is conducted and perceived on board and by maritime stakeholders ashore. We do believe that despite the recent attention from industry and research communities, seafarers will remain a crucial part of the maritime transport system. It is thus unfortunate that the concept 'autonomous ships' has accidently become an indicator of that seafarers soon will become obsolete, which may have negative consequences for the supply of maritime competence in coming years.

The steppingstone for this paper has been the belief that the technical development and its terminology need to be kept in-tuned with changing educational demands and organizational development. The attempt has been to take a critical view on the pre-transition terminology in relation to obstacles and possibilities surrounding the transformation into the next generation of shipping. We have argued that the proper definition of the term 'autonomous' describes something that may never apply to a maritime concept in the shape of a ship. All ships can, and eventually probably will, be given the possibility, but hardly the full right or condition of self-government. We have argued that 'smart ships', or perhaps 'intelligent ships', are more appropriate than 'autonomous'. The former terminology describe the current and future state of technological development without predicting how humans will prefer to use it in any future state of development. Talking about smart or intelligent technology also brings ideas of decision support, rather than something just taking over. Likewise, we argued that the term 'degrees of digitalization' would be more appropriate than 'degrees of autonomy'.

The timeframe for a significant level of implementation of relatively small, unmanned car ferries and cargo vessels in domestic water was estimated to about 10-20 years from now. Any significant level of introduction of worldwide traffic for international unmanned cargo ships was estimated to take more than 40 years. This is due to a number of obstacles that for many years will have impact on the choice for ship owners to adopt now or postpone the decision until later. Moreover, we believe that the timeframe for implementation of unmanned passenger ships for international traffic will remain a question mark for the future.

Finally, the estimated timeframes suggest no threat to the seafaring occupation for coming generation. The content of the occupation will of course change due to the phase of implementation of degree of digitalization, but there will always be a need for maritime knowledge and understanding. This calls for careful updates of curriculums in maritime academies concerning specific competence requirements related to different concepts and combinations of type of ship and traffic area. However, the proper understanding of the real conditions at sea will remain as a fundament for maritime education.

\section{ACKNOWLEDGEMENT}

We would like to acknowledge the Swedish Transport Administration's funding of the project Autonomy and responsibility - The human role in the future of shipping. We also like to thank the project's reference group for in depth 
discussions, lecturers at Kalmar Maritime Academy and all ship officers and pilots who have participated in different phases of the project. Their input has been invaluable to gain a deeper understanding of the future of shipping in the Swedish context. We also like to thank three anonymous reviewers for their valuable comments.

\section{REFERENCES}

Aftonbladet, (2017). Retrieved 2018-12-10: https://www.aftonbladet.se/nyheter/a/MVrQB/har-arvarldens-forsta-sjalvkorande-fartyg--kallas-havets-tesla

Allen, P., Wadsworth, E., \& Smith, A. (2007). The prevention and management of seafarers' fatigue: a review. Int Marit Health, 58(14), 167-177.

DMA, (2016). 'A pre-analysis on autonomous ships'. Retrieved 2019-04-09: https://www.dma.dk/Documents/ Publikationer/Autonome\%20skibe_DTU_rapport_UK.p df

DNV GL, (2018): 'Autonomous and remotely operated ships'. Retrieved 2019-04-09: http://rules.dnvgl.com/ docs/pdf/dnvgl/cg/2018-09/dnvgl-cg-0264.pdf

Government Offices of Sweden, (2017): 'The Swedish climate policy framework'. Retrieved 2019-04-08: https://www.

government.se/495f60/contentassets/883ae8e123bc4e42aa 8d59296ebe0478/the-swedish-climate-policyframework.pdf

Hall, B. H \& Khan, B. (2002). New Economy Handbook. Retrieved 2018-12-10: https://eml.berkeley.edu/ bhhall/ papers/HallKhan03\%20diffusion.pdf

IMO, (2018). 'IMO takes first steps to address autonomous ships' Retrieved 2018-12-10: http://www.imo.org/en/MediaCentre/PressBriefings/Pag es/08-MSC-99-MASS-scoping.aspx

Lighthouse (2018). 'Kompetensförsörjning inom den svenska marina och maritima näringen' Retrieved 201904-09:

https://www.lighthouse.nu/sites/www.lighthouse.nu/file s/webb_2.pdf

Lützhöft, M., Dahlgren, A., Kircher, A., Thorslund, B., \& Gillberg, M. (2010). Fatigue at sea in Swedish shippinga field study. American Journal of Industrial Medicine, 53(7), 733-740. doi:10.1002/ajim.20814

MAREX, (2017). 'Autonomous Ships Before Autonomous Cars?'. Retrieved 2019-04-09: https://www.maritimeexecutive.com/article/autonomous-ships-beforeautonomous-cars

MUNIN project, (2019). Retrieved 2018-12-10: http://www.unmanned-ship.org/munin/

NOVIMAR, (2017). 'NOVIMAR and the vessel train concept'. Retrieved 2019-04-09: https://novimar.eu/concept/

Oxford Living Dictionary (2018). Retrieved 2018-12-10: https://en.oxforddictionaries.com/definition/autonomy
Perrow, C. (1999). Normal Accidents. Living with High-Risk Technologies Princeton. New Jersey: Princeton University Press.

Porathe, Thomas \& Billeso, Bentzen (2015): 'Human Factors in e-Navigation: a study of Dynamic NoGo Area Visualization in Electronic Nautical Charts', A-Mast 2015, International Conference of Advanced Intelligent Maritime Safety and Technology, Korea Advanced Institute for Maritime Safety and Technology, MMU and Korea Research Institute of Ships and Ocean Engineering (KRISO).

Porathe, T; Prison, J \& Y, Man (2014): 'Situation awareness in remote control centres for unmanned ships', Human Factors in Ship Design \& Operation, 26 - 27 February 2014. London, UK.

Praetorius, G, Hult, C \& Sandberg, C (2019) 'Towards autonomous shipping - Exploring potential threats and opportunities in future maritime operations'. Paper accepted for publication at AHFE 2019, July 2019, Washington, D.C., USA.

Relling, Tore, Lützhöft, Margareta, Ostnes, Runar \& Hildre, Hans. (2018). 'A Human Perspective on Maritime Autonomy'. 350-362. 10.1007/978-3-319-91467-1_27.

Rosenberg, Nathan (1972). Factors affecting the diffusion of technology. Explorations in Economic History. Vol. 10(1).

Ryllander, Robert \& Man, Yemao (2016): 'Autonomous safety on vessels: an international overview and trends within the transport sector', Lighthouse.

Sjöfartstidningen, (2016). 'Autonoma fartyg snart verklighet i Finland'. Retrieved 2018-12-10: https://www.sjofartstidningen.se/ autonoma-fartygsnart-verklighet-finland/

Sjöfartstidningen (2016). 'Allt färre vill bli sjöbefäl'. Retrieved 2019-04-09: https://www.sjofartstidningen.se/ allt-farre-vill-bli-sjobefal/

Sjöfartstidningen, (2017). 'Tomma platser på sjöbefälsutbildningarna'. Retrieved 2019-04-09: https:/www.sjofartstidningen.se/tomma-platser-pasjobefalsutbildningarna/

World Maritime News, (2018). 'Rolls-Royce, Intel Launch Autonomous Ship Collaboration'. Retrieved 2019-04-09: https://worldmaritimenews.com/archives/262598/rollsroyce-intel-launch-autonomous-ship-collaboration/

WMU, (2019). 'Transport in 2040: how automation and technology will impact the future of work'. Retrieved 2019-04-09: https://www.wmu.se/news/transport-2040how-automation-and-technology-will-impact-futurework

Yara Birkeland, (2019). 'Yara Birkeland press kit' https://www.yara.com/news-and-media/press-kits/yarabirkeland-press-kit/

Yle Uutiset, (2018). 'Autonomous ferry makes first demonstration voyage in Finland'. Retrieved 2019-04-08: https://yle.fi/uutiset/osasto/news/autonomous ferry_makes_first_demonstration_voyage_in_finland/10 537448 